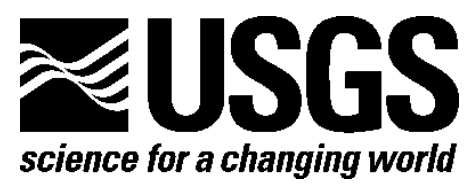

\title{
Events Affecting Gold Exploration in Venezuela Since 1999
}

By David R. Wilburn

Open-File Report 2014-1068

U.S. Department of the Interior

U.S. Geological Survey 


\section{U.S. Department of the Interior \\ SALLY JEWELL, Secretary}

\section{U.S. Geological Survey \\ Suzette M. Kimball, Acting Director}

U.S. Geological Survey, Reston, Virginia: 2014

For more information on the USGS—-the Federal source for science about the Earth, its natural and living resources, natural hazards, and the environment-visit http://www.usgs.gov or call 1-888-ASK-USGS (1-888-275-8747)

For an overview of USGS information products, including maps, imagery, and publications, visit $h t t p: / / w w w . u s g s . g o v / p u b p r o d$

To order this and other USGS information products, visit $h$ ttp://store.usgs.gov

Any use of trade, firm, or product names is for descriptive purposes only and does not imply endorsement by the U.S. Government.

Although this information product, for the most part, is in the public domain, it also may contain copyrighted materials as noted in the text. Permission to reproduce copyrighted items must be secured from the copyright owner.

Suggested citation:

Wilburn, D.R., 2014, Events affecting gold exploration in Venezuela since 1999:

U.S. Geological Survey Open-File Report 2014-1068, 8 p., http://dx.doi.org/10.3133/ofr20141068.

ISSN 2331-1258 (online) 


\section{Contents}

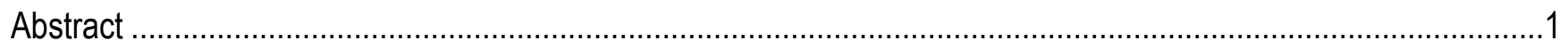

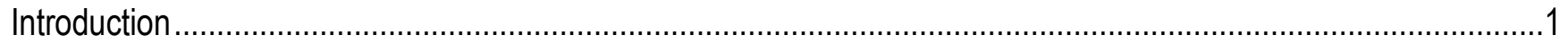

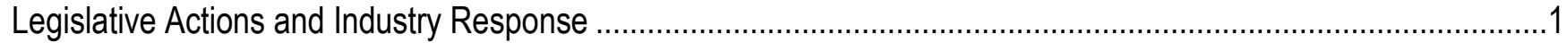

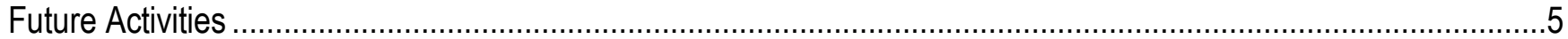

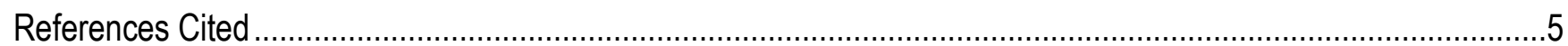

\section{Tables}

1. Gold exploration activities in Venezuela from 2002 through 2012

(Available at $h$ ttp://pubs.usgs.gov/ofr/2014/1068/)

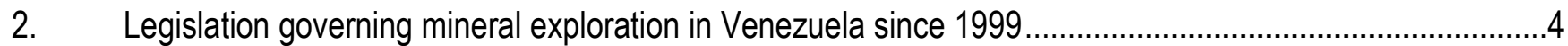





\title{
Events Affecting Gold Exploration in Venezuela Since 1999
}

\author{
By David R. Wilburn
}

\begin{abstract}
The structure of the gold mining industry in Venezuela has changed significantly since 1999 as a result of Government policy changes and industry response to these changes. This report documents the policy decisions that have affected the mining industry, discusses the response of the industry on a site by site basis, and suggests possible effects of these changes on the global economy. For the short term, at least, it appears that these changes have made Venezuela a more difficult place to invest for U.S. and Canadian companies, while investment by Chinese entities has been encouraged.
\end{abstract}

\section{Introduction}

Mineral exploration activity in Venezuela changed significantly over approximately the last decade. Changes were primarily the result of Government policies instituted by Venezuela's President following the election in 1998 and the response of the foreign mining industry to these policies. This President followed a path of " 21 st Century Socialism" that gradually increased Government control of the country's mineral resources and the exploration and mining of those resources, as well as mandated changes that increased domestic ownership and retained a greater portion of production and revenue in the country (Central Intelligence Agency, 2011). These changes led to a restructuring of the Venezuelan mining industry and a decline in gold exploration activities by foreign companies. Although Venezuelan gold production increased 76 percent from 1999 through 2005, the estimated growth in gold production from 2006 through 2011 was only slightly more than 3 percent. It should be noted, however, that 2004 was the last year for which official production statistics were provided to the U.S. Geological Survey (USGS) (Gurmendi, 2011).

\section{Legislative Actions and Industry Response}

The nationalization process, begun after the change in the Venezuelan government in 1998, coupled with an uncertain macroeconomic environment characterized by high inflation and foreign exchange controls, led to reduced foreign investment in mineral exploration and mining by private firms (Gurmendi, 2011). In 1999, the Venezuelan Congress passed legislation (Enabling Law of 1999) that gave the President temporary powers to rule by decree (U.S. Department of State, 2000). One of the first actions of the new President was to revise the mining code (Decree No. 295). Under the new mining law, a combined exploration/mining concession was permitted for a 20 -year period, renewable for a period not to exceed 20 years; exploration concessions granted by the Government were limited to 3 years, with a possible extension of 1 year. At the expiration of a concession, assets were to become the property of Venezuela without compensation (Torres, 2002). Legislation passed in 2001 (Decree No. 
1234) established terms, conditions, and administrative procedures in support of the 1999 mining law. It also reestablished the Corporación Venezolana de Guayana Minerven C.A. (CVGMinerven) and its subsidiaries as the State mining company (Torres, 2003). In 2002, the Venezuelan economy entered a recession, which led to political unrest, a national strike that continued into 2003, and the introduction of currency controls in 2003 (Sullivan, 2009; U.S. Department of State, 2012). Economic conditions improved in 2004, and the Government stimulated mineral exploration activity with the issuance of Decree 3110, which redefined the permissible uses of the Itacama Forest Reserve to allow potential development of the feasibility-stage Las Cristinas gold deposit and exploration of other early-stage gold deposits. Government consolidation of the mining industry continued in 2005 with the annulment of inactive gold and diamond concessions held by private companies and the suspension of exploration and mining permits of concessions where procedures deemed inappropriate by the Government had taken place. The Government also initiated a review of existing concession contracts with the goal of changing them to joint ventures in which the Government would hold at least 60 percent interest (Torres, 2007). In addition, Decree No. 3895 (September 2005) guaranteed that mineral producers would supply the needs of domestic mineral processing companies before they could export products under higher priced, long-term export contracts.

Data compiled by the USGS on gold exploration activities suggest that these conditions have led to a steady decline in exploration activity by foreign companies in Venezuela during the last decade. In 2002, six foreign companies were conducting active exploration programs on six sites. In 2004, Decree 2110 permitted the opening of the Itacama Forest Reserve to exploration, and 12 foreign companies began to actively conduct mineral exploration on multiple sites in Venezuela. Nationalization actions initiated by the Venezuelan Government in 2005 resulted in a sizeable decrease in mineral exploration activities, such that only six companies conducted active exploration in 2005. Only three companies, Rusoro Mining Ltd. (Rusoro) (Canada), Shandong Gold Mining Company Ltd. (China), and ValGold Resources Ltd. (Canada) were actively involved in gold exploration in Venezuela from 2005 to 2009. Data suggest that industry nationalizations, recent legislation, and repatriation delays have tended to discourage gold exploration by some Australian, Canadian, and U.S. companies. At the same time, the Government of Venezuela has encouraged China to invest in gold mining as part of a goal to get the China Development Bank to lend the Government development funds against future gold production (Arson and Davidow, 2011; U.S. Department of State, 2013).

By 2009, Government-mandated restructuring of gold mining companies and expropriation of mineral exploration concessions left the country with only one foreign mining company, Rusoro, a Canadian-Russian controlled company operating under a joint venture agreement with Venezuelan State mining company CVGMinerven. Up to December 15, 2011, Rusoro was engaged in the acquisition, exploration, development, and operation of gold properties in Venezuela. Nationalization of the Venezuelan gold mining industry was formalized in 2011 with Decree No. 8413 giving the Government of Venezuela exclusive rights for the extraction of gold in Venezuela, prohibiting export of gold, and requiring that the State have a minimum 55 percent interest in all exploration and mining ventures (Vyas, 2011). Private companies were still allowed to participate but only as minority partners in a mixed-interest joint venture enterprise, with CRVMinerven (a Venezuelan-Government-owned company) holding 55 percent ownership. A second provision of the 2011 decree required that future legal disputes be resolved in Venezuelan courts (Canadian Business, 2011). This action was likely in response to the filing for international arbitration by three mineral exploration companies (Vanessa Ventures Ltd, Gold Reserve Inc., and Crystallex International Corp.) that claimed they were entitled to financial reimbursement for assets that were expropriated. 
Decree No. 8413 provided a 90-day period (September 16, 2011, to December 15, 2011) for the Government of Venezuela and the companies to negotiate the terms and conditions of the migration of the company's mining assets to the Government-controlled mixed enterprise; Decree No. 8683 subsequently extended this process for an additional 90 days to March 14, 2012 (Gurmendi, 2012). Because Rusoro was unable to agree upon the terms and conditions, its mining concessions expired and its assets reverted to the Venezuelan Government as of March 14, 2012 (Rusoro Mining Limited, 2011). On July 17, 2012, Rusoro filed a request for arbitration with the World Bank's International Centre for Settlement of Investment Disputes (ICSID) (Rusoro Mining Limited, 2012). Venezuela withdrew from the ICSID in January 2012 and no new cases could be brought against it after July 25, 2012.

The incentive for gold exploration in Venezuela has been adversely affected not only by recent nationalization actions but also by actions that influence mining company profitability and resource access. The Central Bank of Venezuela (CBV) passed Resolution 10-01-01 in 2010, which mandated that 50 percent of the gold produced in Venezuela be offered for sale to CBV; if permission was obtained by $\mathrm{CBV}$, the remaining 50 percent could be exported or offered for sale to $\mathrm{CBV}$. CBV had the right to set the currency sale price and exchange rates. For much of 2010, the CBV gold sales price was based on the international U.S. dollar spot gold price less a discount of 1.5 percent, with payment received in Venezuelan bolívar fuerte (Bs.F.) at the official exchange rate of Bs.F. 2.15/\$1.00

(December 31, 2009) and Bs.F. 4.30/\$1.00 (December 31, 2010). As a result, Rusoro reported a foreign exchange loss of \$100.8 million in 2010 compared to a foreign exchange gain of \$1.1 million in 2009 (Rusoro Mining Limited, 2010). In 2009, Rusoro was able to sell a greater quantity of gold at a higher fixed-contract gold price to foreign markets. Foreign companies claimed that the 2011 decree that required all gold produced in Venezuela to be sold to the CBV would affect company profitability, particularly when the gold price set by CBV was lower than the international market price for gold (Rusoro Mining Limited, 2011). Also in 2011, a decision was announced to repatriate 211 tons of foreign-held gold reserves to the CBV and Venezuelan cash reserves to banks in Brazil, China, and Russia (U.S. Department of State, 2011).

Table 1 (available separately at http://pubs.usgs.gov/ofr/2014/1068/) summarizes annual gold exploration activities and developments that affected exploration in Venezuela by site during the period 2002 through 2012. In 2002, 12 sites were actively being explored or mined by foreign interests. Production at two sites was curtailed in 2012, owing to payment and equipment delivery issues (Business News Americas, 2012). By 2013, after nationalization, exploration activity was taking place at five sites, and production continued at two sites. All exploration for and production of gold in 2013 was conducted by CVGMinerven, a Venezuelan-Government-owned company.

Table 2 shows key legislation or legislative activity governing mineral exploration and mining in Venezuela since 1999. Also shown are key actions by the Venezuelan Government and private interests resulting from this legislation. 
Table 2. Legislation governing mineral exploration in Venezuela since 1999.

\begin{tabular}{|c|c|c|}
\hline Year & Legislation & Actions \\
\hline 1999 & Enabling Law of 1999 & Provided President power to rule by decree. \\
\hline \multirow[t]{5}{*}{1999} & Decree No. 295 & $\begin{array}{l}\text { Revised mining code governing the exploration, development, production, } \\
\text { marketing, and transportation of all minerals. }\end{array}$ \\
\hline & & Mining is permitted only through direct participation of Government. \\
\hline & & $\begin{array}{l}\text { Exploration and mining concessions are permitted for a } 20 \text {-year period subject to } \\
\text { Government review. }\end{array}$ \\
\hline & & $\begin{array}{l}\text { Exploration concessions are permitted for } 3 \text { years, with possible } 1 \text {-year } \\
\text { extension. }\end{array}$ \\
\hline & & $\begin{array}{l}\text { At expiration of a concession, assets revert to Government without } \\
\text { compensation. }\end{array}$ \\
\hline \multirow[t]{3}{*}{2001} & Decree No. 1234 & $\begin{array}{l}\text { Established terms, conditions, and administrative procedures in support of } \\
\text { Decree No. } 295 .\end{array}$ \\
\hline & & $\begin{array}{l}\text { Established that the Government has a right of } 30 \text { percent of production revenues } \\
\text { as royalty payment. }\end{array}$ \\
\hline & & $\begin{array}{l}\text { Reestablished Corporación Venezolana de Guayana Minerven C.A. } \\
\text { (CVGMinerven) and exempted CVGMinerven from tax payments. }\end{array}$ \\
\hline 2004 & Decree No. 3110 & $\begin{array}{l}\text { Redefined permitted uses of Itacama Forest Reserve, which allowed exploration } \\
\text { and potential development of Las Cristinas deposit. }\end{array}$ \\
\hline \multirow[t]{3}{*}{2005} & Unspecified legislation & Created new ministry to oversee mining-related activities. \\
\hline & & $\begin{array}{l}\text { Annulled inactive gold and diamond concessions and suspended permits in cases } \\
\text { where appropriate processes had not been followed. }\end{array}$ \\
\hline & & $\begin{array}{l}\text { Stopped granting mining concessions for diamond and gold to private sector } \\
\text { companies; all existing mining concessions and contracts were to be reviewed } \\
\text { with the goal of changing them to joint ventures in which the Government would } \\
\text { hold at least } 60 \text { percent interest. }\end{array}$ \\
\hline 2005 & Decree No. 3895 & $\begin{array}{l}\text { Required mineral producers to meet domestic needs before export contracts, } \\
\text { ensuring domestic mineral processing supply or raw materials and semifinished } \\
\text { products. }\end{array}$ \\
\hline \multirow[t]{2}{*}{2007} & Unspecified legislation & $\begin{array}{l}\text { Initiated foreign exchange controls, requiring Government approval for export of } \\
\text { funds. }\end{array}$ \\
\hline & & $\begin{array}{l}\text { Legislature defeated proposal that would allow President to expropriate private } \\
\text { property by decree. }\end{array}$ \\
\hline 2010 & $\begin{array}{l}\text { Transaction System for } \\
\text { Foreign Currency } \\
\text { Denominated } \\
\text { Securities }\end{array}$ & $\begin{array}{l}\text { In January, devalued tier } 1 \text { currency to } 2.60 \text { Venezuelan bolívar fuerte (Bs.F.): } \\
1 \text { U.S. dollar; tier } 2 \text { currency to } 4.30 \text { Bs.F.: } 1 \text { U.S. dollar. In December, } \\
\text { established uniform exchange rate of } 4.30 \text { Bs.F.: U.S. dollar. Increased allowance } \\
\text { of gold exports to reach } 50 \text { percent of production. }\end{array}$ \\
\hline \multirow[t]{2}{*}{2011} & Decree No. 8413 & $\begin{array}{l}\text { Gave State exclusive right for the extraction of gold in Venezuela and banned } \\
\text { gold exports. }\end{array}$ \\
\hline & & $\begin{array}{l}\text { Nationalization decree gave companies } 90 \text { days to form joint venture with } \\
\text { Government enterprise, where Government retains } 55 \text { percent ownership and } \\
\text { receives } 13 \text { percent royalties. If company fails to reach agreement, all company } \\
\text { concessions, contracts, and assets revert to the Government. }\end{array}$ \\
\hline 2011 & Decree No. 8683 & $\begin{array}{l}\text { Negotiation period deadline extended by an additional } 90 \text { days to March 14, } \\
2012 .\end{array}$ \\
\hline \multirow[t]{3}{*}{2012} & Industry response & Three gold mining arbitration cases in international court. \\
\hline & & Rusoro Mining Limited filed request for international arbitration. \\
\hline & & $\begin{array}{l}\text { Rusoro assets reverted to the Government of Venezuela; CVGMinerven, a } \\
\text { Government-owned company, assumed control of Rusoro mines. }\end{array}$ \\
\hline
\end{tabular}




\section{Future Activities}

Economic and political uncertainties, a history of actual and threatened nationalizations, increased Government intervention in the economy, and a restrictive legal framework make Venezuela's investment climate less welcoming than it once was. Although no prior registration is generally required for foreign investment, subsequent registration with the Superintendent of Foreign Investments is required. Repatriation of capital and dividends is legally allowed but is subject to the exchange rate regime. In practice, few companies have been able to repatriate dividends since 2008 (Gurmendi, 2014). Foreign currency brought in to cover local expenses that are exchanged at the official rate made investment costs high. Foreign direct investment (FDI) into Venezuela in recent years has lagged behind that of most other Latin American countries. The uncertain macroeconomic and political environment of Venezuela could continue to discourage the level of private mineral exploration and investment in the country until the legal framework and economic conditions in the country change significantly. Venezuelan voters elected a new President in 2013; the new administration is continuing existing nationalization policies of the mining industry. It is possible that Venezuela will continue to encourage investment and strategic alliances with companies from Brazil, China, Iran, Italy, and Russia as a means of continuing production of its existing mining operations and to develop its abundant natural resources, perhaps by means of infrastructure for resource deals similar to those being structured in parts of Africa. It is also unclear whether the change in administration would affect the 2012 memorandum of understanding between Chinese and Venezuelan officials that has the potential to provide investment funds that may be used for the development of the Brisas and Las Cristinas gold deposits (Williams, 2012). As of 2007, Las Cristinas had a reported proven and probable reserve of 464.4 million metric tons grading 1.13 grams per metric ton $(\mathrm{g} / \mathrm{t})$ gold containing 16.9 million troy ounces, or the equivalent of 525 metric tons of gold (Crystallex International Corporation, 2007).

A number of gold-related mining companies have filed claims against the Venezuelan Government. As of January 2013, only one claim has received a ruling by the ICSID, which dismissed claims brought by Vannessa Ventures Ltd. on mining and energy seizures that started in 1999, ruling that the mining company's rights under the Canada-Venezuela bilateral investment treaty were not violated (Crooks and Orozco, 2013). Venezuela is facing 29 pending cases at the ICSID, of which 4 involve gold mining companies.

\section{References Cited}

Arson, C.J., and Davidow, Jeffrey, eds., 2011, China, Latin America, and the United States-The New Triangle 2011: Woodrow Wilson International Center for Scholars, Institute of the Americas, Chinese Academy of Social Sciences, 33 p., accessed October 17, 2013, at http://www.wilsoncenter.org/sites/default/files/LAP_120810_Triangle_rpt.pdf.

Business News Americas, 2012, Minerven contractors hold 30-hour rally, demand US\$18mn, accessed July 10, 2013, at http://bnamericas.com/news/mining/minerven-contractors-hold-30-hour-rallydemand-US18mn\#.

Canadian Business, 2011 (September 22), Rusoro Mining says Venezuela wants 55 per cent ownership of new gold company: Toronto, Ontario, Canada, Canadian Press, accessed September 29, 2011, at http://www.canadianbusiness.com/print/46874.

Central Intelligence Agency, 2011, The world factbook, accessed January 7, 2014, at https://www.cia.gov/library/publications/the-world-factbook/geos/ve.html. 
Crooks, Nathan, and Orozco, Jose, 2013, World Bank court rules for Venezuela in gold mining case: Bloomberg.com, January 18, accessed June 24, 2013, at http://www.bloomberg.com/news/print/201301-18/world-bank-court-rules-for-venezuela-in-mining-case-correct.html.

Crystallex International Corporation, 2007, Crystallex updates resource and reserve estimates for the Las Cristinas deposit, September 24, accessed October 21, 2013, at http://www.crystallex.com/News/PressReleases/PressReleaseDetails/2007/CrystallexUpdatesResourc eandReserveEstimatesfortheLasCristinasDeposit987/default.aspx.

Gurmendi, A.C., 2011, The mineral industry of Venezuela, in Area reports - International-Latin America and Canada: U.S. Geological Survey Minerals Yearbook 2009, v. III, p. 18.1-18.9. (Also available at http://minerals.er.usgs.gov/minerals/pubs/country/2009/myb3-2009-ve.pdf.)

Gurmendi, A.C., 2012, The mineral industry of Venezuela (Advance release), in Area reportsInternational_-Latin America and Canada: U.S. Geological Survey Minerals Yearbook 2011, v. III, p. 16.1-16.10, accessed March 26, 2014, at http://minerals.er.usgs.gov/minerals/pubs/country/2011/myb3-2011-ve.pdf.

Gurmendi, A.C., 2014, The mineral industry of Venezuela (Advance release), in Area reportsInternational-Latin America and Canada: U.S. Geological Survey Minerals Yearbook 2012, v. III, p. 15.1-15.9, accessed March 26, 2014, at http://minerals.er.usgs.gov/minerals/pubs/country/2012/myb32012-ve.pdf.

Rusoro Mining Limited, 2010, 2010 Management discussion \& analysis, 26 p., accessed September 26, 2011, at http://www.rusoro.com/i/pdf/2020-YE-MDA.pdf.

Rusoro Mining Limited, 2011, 2011 Management discussion \& analysis, 23 p., accessed June 12, 2013, at $h t t p: / / w w w . r u s o r o . c o m / i / p d f / 2011-M D A-D E C 31 . p d f$.

Rusoro Mining Limited, 2012, Rusoro files international arbitration against the Venezuelan Government, press release, accessed June 25, 2013, at http://www.rusoro.com/s/News_Releases.asp?printVersion=now\&ReportID $=537416$.

Sullivan, M.P., 2009, Venezuela-Political conditions and U.S. policy: Congressional Research Service Report RL32488, July 28, accessed November 15, 2012, at http://www.fas.org/sgp/crs/row/RL32488.pdf.

Torres, I.E., 2002, The mineral industry of Venezuela, in Area reports-International-Latin America and Canada: U.S. Geological Survey Minerals Yearbook 2000, v. III, p. 17.1-17.8. (Also available at http://minerals.er.usgs.gov/minerals/pubs/country/2000/9523000.pdf.)

Torres, I.E., 2003, The mineral industry of Venezuela, in Area reports-International-Latin America and Canada: U.S. Geological Survey Minerals Yearbook 2001, v. III, p. 17.1-17.11. (Also available at http://minerals.er.usgs.gov/minerals/pubs/country/2001/vemyb01r.pdf.)

Torres, I.E., 2007, The mineral industry of Venezuela, in Area reports-International-Latin America and Canada: U.S. Geological Survey Minerals Yearbook 2005, v. III, p. 16.1-16.9. (Also available at http://minerals.er.usgs.gov/minerals/pubs/country/2005/myb3-2005-ve.pdf.)

U.S. Department of State, 2000, Venezuela-1999 country reports on economic policy and trade practices: U.S. Department of State, March, 13 p., accessed September 23, 2011, at http://www.state.gov/www/issues/economic/trade reports/1999/venezuel.pdf.

U.S. Department of State, 2011, Background note-Venezuela, accessed September 28, 2011, at http://www.state.gov/r/pa/ei/bgn/35766.htm.

U.S. Department of State, 2012, Venezuela - Country specific information, accessed November 14, 2012, at http://travel.state.gov/travel/cis_pa_tw/cis/cis_1059.html.

U.S. Department of State, 2013, Venezuela-2012 investment climate statement, accessed June 21, 2013, at http://www.state.gov/e/eb/rls/othr/ics/2012/191262.htm. 
Vyas, Kejal, 2011, Venezuela bans gold exports - State to hold 55\% in mining ventures: Wall Street Journal Online, September 19, accessed September 23, 2011, at http://online.wsj.com/article/SB10001424053111904194604576581012740465784.html.

Williams, Lawrence, 2012, Next Chinese gold target-Venezuela's huge Las Cristinas project, accessed September 24, 2012, at http://www.mineweb.com/mineweb/content/en/mineweb-goldnews? oid $=159038 \&$ sn $=$ Detail. 
ISSN 2331-1258 (online)

http://dx.doi.org/10.3133/ofr2014xxxx 